\title{
Combined intramedullary and intradural extramedullary spinal metastases in malignant melanoma
}

\author{
Michael Kevin O'Reilly, Gavin Sugrue, Danielle Byrne, Peter MacMahon
}

Department of Radiology, Mater Misericordiae University Hospital, Dublin, Ireland

\section{Correspondence to} Dr Michael Kevin O'Reilly, Radiology, Mater Misericordiae University Hospital, Eccles Street, Dublin 7, Ireland; michael.oreilly3@gmail.com

Accepted 16 March 2017

\section{DESCRIPTION}

A patient in their 30s presented with a 3-day history of lower back pain, lower limb weakness and new onset of urinary incontinence. The patient had a history of metastatic melanoma, including to brain, for which they had previously been treated with adjuvant chemotherapy and radiotherapy. Clinical exam revealed a palpable bladder at the umbilicus and reduced power in the lower limbs bilaterally.

An MRI whole spine with gadolinium contrast agent revealed multiple enhancing lesions at the T5/6, T9 and T12-L3 levels, pronounced spinal cord oedema and a markedly distended bladder (figures 1 and 2). The location of these lesions within the spinal canal was mixed, including intramedullary metastases (ie, within the substance of the spinal cord) and intradural extramedullary metastases (ie, in the subarachnoid space but extrinsic to the cord). Lesions obliterated the cauda equina resulting in a cauda equina syndrome.

The three possible locations for spinal metastases are intradural intramedullary, commonly shortened to intramedullary, intradural extramedullary and extradural (figure 3). To our knowledge, this is the first reported case of mixed intramedullary and intradural extramedullary spinal cord metastases from malignant melanoma.

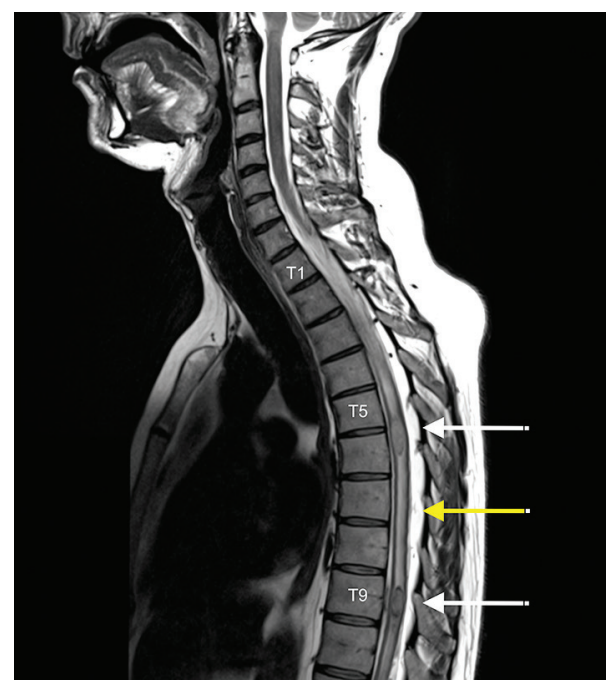

The white arrows demonstrate the typical appearance of intradural intramedullary spinal metastases with intense surrounding vasogenic oedema noted in the adjacent
To cite: O'Reilly MK, Sugrue $\mathrm{G}$, Byrne D, et al. BMJ Case Rep Published Online First: [please include Day Month Year]. doi:10.1136/ bcr-2017-220031

CrossMark

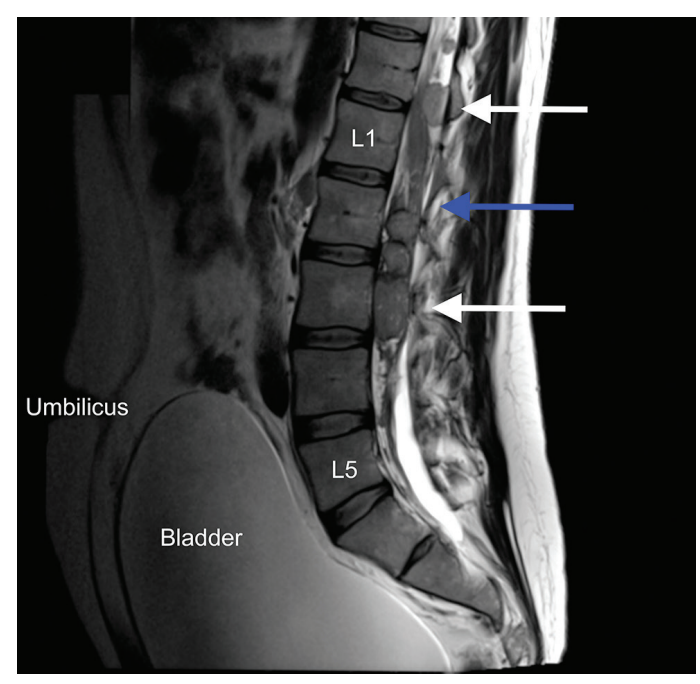

Figure 2 T2 sagittal MRI of the lumbar spine. The white arrows show multiple intradural extramedullary metastases in the region of the cauda equina (blue arrow). The bladder is massively distended to the level of the umbilicus, in keeping with the patient's presenting condition of urinary incontinence (overflow).

Spinal extradural metastases affect up to $10 \%$ of all patients with cancer. ${ }^{1}$ Intradural metastases are rare but as systemic therapy improves their incidence has been reported to be on the increase. ${ }^{2}$ Lung, brain and breast cancer metastases are among the most common. ${ }^{2}$

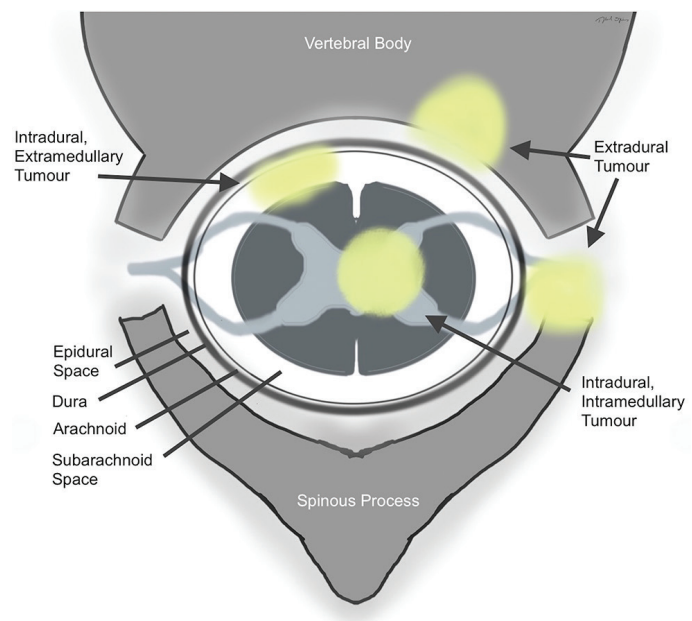
spinal cord (yellow arrow).
Figure 3 The possible anatomical locations for spinal metastases. 
Intradural spinal cord metastases have four proposed routes of spread that include (1) haematogenous-arterial and through the venous plexus (of Batson), (2) in the cerebrospinal fluid-'drop metastases', (3) in the central canal, involving the perineural lymphatics or (4) invasion from adjacent structures. ${ }^{3}$

\section{Learning points/take home message}

- Spinal cord metastases are not a single entity. They have three distinct possible anatomical locations: intramedullary, intradural extramedullary and extradural.

- Extradural spinal cord metastases are the most common location. Concomitant intradural and extradural metastases are uncommon.

- In the evaluation of neurological symptoms in patients with malignant melanoma, it is important to assess for intracranial metastases and intradural spinal lesions.
The patient received immediate high-dose steroids, external beam radiotherapy and was started on pembrolizumab, a humanised monoclonal immunoglobulin. On follow-up at 3 months, the patient had regained bladder control and power in his legs, but died 10 months later from complications of the disease.

Competing interests None declared.

Patient consent Not obtained.

Provenance and peer review Not commissioned; externally peer reviewed.

Data sharing statement MOR was involved in the conception, data acquisition, writing and design of the manuscript. GS, DB and PM were involved in the conception, writing and editing of the manuscript. All authors have reviewed the final version and approved it.

\section{REFERENCES}

1 Mut M, Schiff D, Shaffrey ME. Metastasis to nervous system: spinal epidural and intramedullary metastases. J Neurooncol 2005;75:43-56.

2 Payer S, Mende KC, Westphal M, et al. Intramedullary spinal cord metastases: an increasingly common diagnosis. Neurosurg Focus 2015;39:E15.

3 Rykken JB, Diehn FE, Hunt $\mathrm{CH}$, et al. Intramedullary spinal cord metastases: MR and relevant clinical features from a 13-year institutional case series. AJNR Am $J$ Neuroradiol 2013:34:2043-9.

Copyright 2017 BMJ Publishing Group. All rights reserved. For permission to reuse any of this content visit

http://group.bmj.com/group/rights-licensing/permissions.

BMJ Case Report Fellows may re-use this article for personal use and teaching without any further permission.

Become a Fellow of BMJ Case Reports today and you can:

- Submit as many cases as you like

- Enjoy fast sympathetic peer review and rapid publication of accepted articles

- Access all the published articles

- Re-use any of the published material for personal use and teaching without further permission

For information on Institutional Fellowships contact consortiasales@bmjgroup.com

Visit casereports.bmj.com for more articles like this and to become a Fellow 